\title{
Drug Administered Identifier
}

National Cancer Institute

\section{Source}

National Cancer Institute. Drug Administered Identifier. NCI Thesaurus. Code C69275.

An identifier for a drug that was administered. 